\title{
But There Is Oxidized Glutathione in Streptococcus faecalis
}

\author{
REIJO LAHTI, PAULI VUORINEN and MIKKO SUONPÄÄ
}

Department of Biochemistry, University of Turku, SF-20500 Turku 50, Finland

Redox state of glutathione in Streptococcus faecalis was examined. Cells taken from the exponential phase of growth contained reduced and oxidized glutathione at concentrations of 2.5 and $1.1 \mathrm{mM}$, respectively, whereas at the stationary phase the corresponding values were 0.35 and $0.3 \mathrm{mM}$, Our results indicate that, contrary to common opinion, as much as $23-31 \%$ of total glutathione is in its oxidized form.

It has been generally thought that there is no oxidized glutathione (GSSG) in bacterial cells. ${ }^{1,2}$ However, we think that this view is due in part to a lack of reliable methods for the determination of GSSG. $^{3}$ The most commonly used method, presented by Tietze, ${ }^{4}$ involves complexing of reduced glutathione (GSH) with $N$-ethylmaleimide (NEM), extraction of the unreacted NEM with ether, and measurement of the yellow colour formed as a result of incubation of GSSG in the presence of glutathione reductase (EC 1.6.4.2), NADH, and 5,5'dithiobis(2-nitrobenzoic acid) (DTNB). However, $w^{3}$ and others ${ }^{5,6}$ have shown that complete extraction of NEM, a potent inhibitor of glutathione reductase, ${ }^{7}$ is very difficult. So it is obvious that the most commonly used method for the determination of GSSG decribed by Tietze ${ }^{4}$ should not be used since it may lead to a severe underestimation of intracellular GSSG levels.

We have recently described ${ }^{3}$ a simple modification of Tietze's ${ }^{4}$ method in which $\mathrm{CuCl}$ instead of NEM is used in the precipitation of GSH. Making use of this method we determined intracellular GSSG concentrations in Streptococcus faecalis, and found that there is oxidized glutathione in bacteria. The details of these studies are described in this paper.

\section{MATERIALS AND METHODS}

Streptococcus faecalis ATCC 8043 was grown in a rich medium at $37^{\circ} \mathrm{C}$ in a rotary shaker and growth was followed by measuring the turbidity of the culture with a Klett-Summerson colorimeter as described by Lahti \& Heinonen. ${ }^{8}$ Samples $(2.5 \mathrm{ml})$ taken from the culture were rapidly chilled by $1: 1$ dilution with ice-cold $0.15 \mathrm{M} \mathrm{NaCl}$ containing 10 $\mathrm{mM}$ sodium azide. Cells were harvested by centrifugation $\left(5000 \mathrm{~g}, 10 \mathrm{~min}, 4^{\circ} \mathrm{C}\right)$, and washed once with ice-cold $0.15 \mathrm{M} \mathrm{NaCl}$ containing $10 \mathrm{mM}$ sodium azide. The cells were stored at $-70^{\circ} \mathrm{C}$.

Glutathione was extracted from the cells by shaking $\left(20 \min 37^{\circ} \mathrm{C}\right)$ in buffer-toluene mixture $(0.1$ $\mathrm{ml}$ toluene in $5 \mathrm{ml}$ of $0.1 \mathrm{M}$ potassium phosphate buffer pH 7.5 containing $5 \mathrm{mM}$ Na-EDTA). The extracts were centrifuged $\left(5000 \mathrm{~g}, 10 \mathrm{~min}, 4^{\circ} \mathrm{C}\right)$ and glutathione was measured in the supernatant.

Total glutathione was determined as described by Tietze. ${ }^{4}$ In this method GSSG is reduced to GSH by glutathione reductase and $\mathrm{NADH}$, and a yellow GSH-5,5'-dithiobis(2-nitrobenzoic acid) (DTNB) complex is formed which can be measured with a Klett-Summerson colorimeter using filter $42(390$ $-440 \mathrm{~nm}$ ). The reaction mixture was as follows: 4 $\mathrm{ml}$ of diluted cell extracts (dilution with $0.1 \mathrm{M}$ potassium phosphate buffer $\mathrm{pH} 7.5$ containing 5 mM Na-EDTA) containing up to 0.3 and $0.2 \mathrm{nmol}$ glutathione per reaction mixture for total and oxidized glutathione, respectively; $1 \mathrm{ml}$ of $1.1 \mathrm{mM}$ $\mathrm{Na}-\mathrm{NADH}, 0.025 \mathrm{ml}$ (about 3.5 units) of glutathione reductase, and $0.1 \mathrm{ml}$ of $10 \mathrm{mM}$ DTNB.

GSSG was determined in the same way after precipitation of $\mathrm{GSH}$ with $\mathrm{CuCl}^{3} \mathrm{CuCl}$ as powder $(20 \mathrm{mg})$ was added to $5 \mathrm{ml}$ of diluted extracts containing up to $0.25 \mathrm{nmol}$ glutathione. After $30 \mathrm{~s}$ of vigorous mixing with a Vortex mixer at room temperature (about $20^{\circ} \mathrm{C}$ ) the suspension was 
centrifuged $\left(5000 \mathrm{~g}, 10 \mathrm{~min}, 4^{\circ} \mathrm{C}\right)$ and GSSG was determined in the supernatant. As $95 \%$ of GSH was precipitated by $\mathrm{CuCl}$, this had to be taken into account in the calculations. Furthermore $\mathrm{CuCl}$ was slightly oxidized under our experimental conditions (the solution became blue), resulting in a partial inhibition of glutathione reductase. ${ }^{3}$ To overcome this effect a GSSG standard was determined in the presence of $\mathrm{CuCl}$. For the estimation of intracellular glutathione the volume of the bacterial cells in each sample was calculated as described by Moses and Sharp. ${ }^{9}$

\section{RESULTS AND DISCUSSION}

$\mathrm{We}^{3}$ have recently introduced a simple modification of Tietze's method ${ }^{4}$ for the determination of GSSG in which $\mathrm{CuCl}$ is used instead of NEM in the precipitation of GSH. In this system care must be taken not to exceed the capacity of $\mathrm{CuCl}$ to precipitate glutathione. Therefore when oxidized glutathione was determined the samples taken from the culture were diluted (with potassium phosphate buffer $\mathrm{pH} 7.5$ containing $5 \mathrm{mM} \mathrm{Na}-$ EDTA) so that they contained at most $0.20 \mathrm{nmol}$ glutathione per reaction mixture in order to ensure efficient precipitation of GSH (Fig. 1).

Table 1 shows the concentrations of oxidized and reduced glutathione found in the exponential and stationary phase of growth in Streptococcus faecalis.

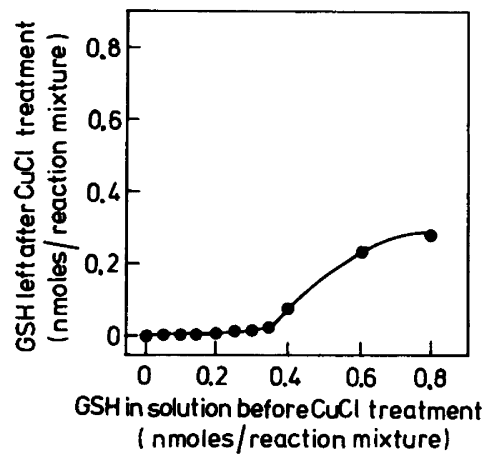

Fig. 1. Precipitation of GSH with $\mathrm{CuCl}$. Different dilutions of GSH standard were made in $0.1 \mathrm{M}$ potassium phosphate buffer $\mathrm{pH} 7.5$ containing 5 mM Na-EDTA. Then $\mathrm{CuCl}$ treatment and GSH measurement were performed as described in Materials and Methods. - , indicates the concentration of GSH observed in the solution after $\mathrm{CuCl}$ treatment.
Table 1. Glutathione content in Streptococcus faecalis. $\mathrm{E}$ and $\mathrm{S}$ indicate samples taken from the exponential and stationary phase of growth, respectively. $\mathrm{KU}_{62}$ denotes to the turbidity of the culture as Klett-Summerson colorimetric units. For further detailes see Materials and Methods.

\begin{tabular}{llll}
\hline Phase of growth & $\begin{array}{l}\text { GSH } \\
(\mathrm{mM})\end{array}$ & $\begin{array}{l}\text { GSSG } \\
(\mathrm{mM})\end{array}$ & $\begin{array}{l}\text { GSSG } \\
(\% \text { of total })^{a}\end{array}$ \\
\hline $\mathrm{E}_{1}\left(\mathrm{KU}_{62}=43\right)$ & 2.44 & 1.07 & 23.4 \\
$\mathrm{E}_{2}\left(\mathrm{KU}_{62}=62\right)$ & 2.54 & 1.10 & 23.2 \\
$\mathrm{~S}_{1}\left(\mathrm{KU}_{62}=195\right)$ & 0.37 & 0.34 & 32.3 \\
$\mathrm{~S}_{2}\left(\mathrm{KU}_{62}=195\right)$ & 0.33 & 0.25 & 30.1 \\
\hline
\end{tabular}

${ }^{a}$ Total glutathione $=$ GSH $+2 \times$ GSSG .

The concentrations of total glutathione calculated from Table 1 are close to those observed with other bacteria. ${ }^{1,10,11}$ However, it is most remarkable that, contrary to common opinion, ${ }^{1,2}$ there is a significant amount of oxidized glutathione in $S$. faecalis; 23 and $31 \%$ of total glutathione in the exponential and stationary phases, respectively (Table 1). Complete recoveries for GSH (data not shown) and GSSG (Table 2) indicate that GSH is not oxidized to GSSG during the manipulation of samples. This is further supported by the fact that similar amounts of GSSG were observed by extracting glutathione from the cells by ethanol immediately after filtration of the samples taken from the culture. However, for some unknown reason, the ethanol extraction was not precise enough to be used routinely, and so it was omitted.

We think it quite natural that there is GSSG in the cells because in other redox-systems $\left(\mathrm{NAD}^{+}\right.$ $\left.-\mathrm{NADH}, \mathrm{NADP}^{+}-\mathrm{NADPH}\right)$ the oxidized form exists as a majority. ${ }^{12-16}$

Rather low $K_{\mathrm{m}}$-values for GSSG $(0.01-0.1 \mathrm{mM})$ have generally been observed with glutathione reductase, and this has been thought to support the view that the intracellular concentration of GSSG is very low. ${ }^{17-19}$ However, it must be recognized that a $K_{\mathrm{m}}$-value in two-substrate systems is a rather complicated concept; the magnitude of $K_{\mathrm{m}}$-value may depend, for instance, on the concentrations of both substrates. ${ }^{20}$ No matter how tightly the enzyme binds GSSG, complete reduction will not occur unless the concentration of NADPH available for glutathione reductase at least equals the GSSG concentration. In addition to glutathione reductase, several enzymes catalyzing biosynthetic reactions require NADPH as a reducing agent. Hence it is 
Table 2. Recovery of oxidized glutathione. Oxidized glutathione (GSSG) was added to the samples taken from the exponential $\left(\mathrm{KU}_{62}=20\right)$ and stationary $\left(\mathrm{KU}_{62}=180\right)$ phases of growth. Preparation of the cell extracts by toluene, precipitation of $\mathrm{GSH}$ by $\mathrm{CuCl}$, and $\mathrm{GSSG}$ measurement were carried out as described in Materials and Methods.

\begin{tabular}{|c|c|c|c|c|}
\hline Phase of growth & $\begin{array}{l}\text { GSSG observed }{ }^{a} \\
\text { in the sample }\end{array}$ & $\begin{array}{l}\text { GSSG added }{ }^{a} \\
\text { to the sample }\end{array}$ & $\begin{array}{l}\text { GSSG observed }{ }^{a} \\
\text { from the mixture }\end{array}$ & $\begin{array}{l}\text { Recovery } \\
(\%)\end{array}$ \\
\hline Exponential phase of growth & 0.054 & 0.05 & 0.106 & 102 \\
\hline Stationary phase of growth & 0.049 & 0.05 & 0.095 & 96 \\
\hline
\end{tabular}

${ }^{a}$ nmol GSSG/reaction mixture.

difficult to anticipate the concentration of NADPH available for glutathione reductase in the cells. It can be mentioned, for interest, that with glutathione reductase of Chromatium vinosum Chun and Hurlbert ${ }^{21}$ observed a rather high $K_{\mathrm{m}}$-value for GSSG $(7 \mathrm{mM})$. They thought that the real substrate for this enzyme could not be GSSG but some other disulfide existing in cells in much higher concentrations. The internal concentrations of GSSG found in S. faecalis would make it possible for the glutathione reductase of $C$. vinosum to use GSSG as a substrate.

\section{REFERENCES}

1. Loewen, P. C. Can. J. Biochem. 57 (1979) 107.

2. Jocelyn, P. C. Biochemistry of the SH Group, Academic, New York 1972, p. 180.

3. Lahti, R. and Vuorinen, P. Finn. Chem. Lett. $1-2$ (1981) 18.

4. Tietze, F. Anal. Biochem. 27 (1969) 502.

5. Hissin, P. J. and Hilf, R. Anal. Biochem. 74 (1976) 214.

6. Griffith, O. W. Anal Biochem. 106 (1980) 207.

7. Colman, R. F. and Black, S. J. Biol. Chem. 240 (1965) 1796.

8. Lahti, R. and Heinonen, J. Acta Chem. Scand. B 35 (1981) 33.

9. Moses, V. and Sharp, P. B. J. Gen. Microbiol. 71 (1972) 181.

10. Apontoweil, P. and Berends, W. Biochim. Biophys. Acta 399 (1975) 1.

11. Fahey, R. C., Brown, W. C., Adams, W. B. and Worsham, M. B. J. Bacteriol. 133 (1978) 1126.

12. Brunker, R. and Brown, O. Microbios 4 (1971) 193.

13. Lundquist, R. and Olivera, B. J. Biol. Chem. 246 (1971) 1107.

14. Wimpenny, J. and Firth, A. J. Bacteriol. 111 (1972) 24.

Acta Chem. Scand. B 36 (1982) No. 2
15. Lilius, E.-M. Dissertation, Department of Biochemistry, University of Turku, Turku 1978.

16. Karl, D. M. Microbiol. Rev. 44 (1980) 739.

17. Mavis, R. D. and Stellwagen, E. J. Biol. Chem. 243 (1968) 809.

18. Scott, E. M., Duncan, I. W. and Ekstrand, W. J. Biol. Chem. 238 (1963) 3928.

19. Flohe, L. and Günzler, A. Glutathione: Metabolism and Function, Raven, New York 1975, pp. $17-34$.

20. Ferdinand, W. Biochem. J. 98 (1966) 278.

21. Chun, Y. C. and Hurlbert, R. E. J. Bacteriol. $123(1975) 203$.

Received October 16, 1981. 